\title{
An Epidemiological Study of Child Health and Nutrition in a Northern Swedish County
}

AKADEMISK AVHANDLING

som med vederbörligt tillstånd $\mathrm{av}$

Medicinska Fakulteten vid Universitetet i Umeå

för vinnande av medicine doktorsgrad

kommer att offentligen försvaras $i$

Samhällsvetarhuset, sal D,

lördagen den 15 maj 1971 kl. 9 f. m.

av

GOSTA SAMUELSON

Med. lic. 
From the Department of Paediatrics, University Hospital, Umeå, Sweden

AN EPIDEMIOLOGICAL STUDY OF CHILD HEALTH AND NUTRITION IN A NORTHERN SWEDISH COUNTY

by

Gösta Samuels on

Umeå 1971 
T ranslated by

BARBARA STEELE 
This thesis is a summary of the following original papers:

I. An epidemiological study of child health and nutrition in a northern Swedish county. I. Food consumption survey. Acta Paediat Scand, 60: Supp1. $214,1971$.

II. An epidemiological study of child health and nutrition in a northern Swedish county. II. Methodological study of the recall technique. Nutr Metabol, 12: 321, 1970.

III. An epidemiological study of child health and nutrition in a northern Swedish county. III. Medical and anthropometrical examinations. Acta Paediat Scand, 60, 1971. In press.

IV. An epidemiological study of child health and nutrition in a northern Swedish county. IV. Haematological investigations, especially in regard to iron deficiency anaemia. Acta Paediat Scand, 60, 1971. In press. In collaboration with S. Sjölin.

V. An epidemiological study of child health and nutrition in a northern Swedish county. V. Oral health studies. Odont. Rev, 22, 1971. In press. In collaboration with $\mathrm{H}$. Grahnén and G. Lindström.

VI. An epidemiological study of child health and nutrition in a northern Swedish county. VI. Relationship between general and oral health, food habits and socio-economic conditions. In collaboration with H. Grahnén and E. Arvidsson. To be published, 1971.

In the text, the above papers will be referred to by the Roman numerals I - VI. 


\section{INTRODUCTION}

In the past two decades, the importance of diet for children's health and development has been increasingly emphasized. However, there have been few investigations in industrialized countries combining a study of children's diets with a study of their general and oral health status and socio-economic situation. In Sweden during the 1950's and 1960's, preventive child health care was extended, and the health and nutritional status of most groups in the community changed. There is reason to believe that changes in diet and dietary habits accompanied the general social changes that occurred during this period.

One of the earliest epidemiological nutritional investigations in Sweden was that of Odin et al. in 1929-31 (20). His study included both adults and children and gave a general picture of the dietary habits, general and oral health status and socio-economic conditions at that time. During the 1950's and 1960's, the health and nutrition of children up to three years of age was carefully investigated by Mellander, Vahlqvist \& Mellbin (17) in the 'Norrbotten study'. There have been only two other Swedish epidemiological studies in which child health, dietary intake and socio-economic conditions have been investigated, namely Mellbin's study of Lapp children (18) and Sterky's study of diabetic children in Stockholm (24), which included a control group of healthy school children.

The present epidemiological study was carried out in approximately the same region in the northern part of Sweden as that in which Odin conducted his investigation. 


\section{THE AIMS OF THE INVES TIGATION}

The aims of the investigation were:

To investigate the food habits and nutritional intake of $4-, 8$ and 13-year-old children in three areas of Västerbotten county which differ from one another both geographically and, in part, socio-economically.

To investigate the usefulness of the recall method in studies of children's food consumption by performing a methodological study within the framework of the 'food consumption survey', using the double-portion technique.

To determine the health and nutritional status of the children taking part in the investigation.

To determine the prevalence of haematological disorders, especially of iron-deficiency anaemia in the age groups investigated.

To obtain information about ha emoglobin concentration ( $\mathrm{Hb}$ ), packed red cell volume (PCV), mean red cell haemoglobin concentration (MCHC) and transferrin concentration. In this part of the study, a l-year-old group was also included.

To carry out an epidemiological, odontological study parallel to the medical investigation, aimed mainly at determining the prevalence of caries and gingivitis.

To explore the relationship between general and oral health, dietary habits and socio-economic conditions, and to elucidate the changes in food habits and health status that have occurred since the time of Odin's study (20).

\section{MATERIAL}

All of the 1401 children who took part in the investigation were selected from three areas of Västerbotten county, 
namely the city of Umeå and two rural areas, the inland a rea and the mountain foreland. All the children were selected from the county population register (I).

The composition of the material and its sex and age distribution are shown in Table 1.

Table 1. Age, sex and geographical distribution of the 1401 children studied

\begin{tabular}{|c|c|c|c|c|c|c|}
\hline \multirow{2}{*}{ Age group } & \multicolumn{2}{|c|}{4 years } & \multicolumn{2}{|c|}{8 years } & \multicolumn{2}{|c|}{13 years } \\
\hline & Boys & Girls & Boys & Girls & Boys & Girls \\
\hline City of Umeå & 99 & 99 & 100 & 100 & 100 & 100 \\
\hline Inland a rea & - & - & 98 & 90 & 91 & 111 \\
\hline Mountain foreland & - & - & 99 & 96 & 114 & 104 \\
\hline Total & 99 & 99 & 297 & 286 & 305 & 315 \\
\hline
\end{tabular}

The urban children were from the city of Umeå. In the age groups 4-, 8- and 13-years, every second child was selected from those parts of the city that are purely urban in character.

In the inland area, all children in age groups 8- and 13 -years in the two communes of Lycksele and Assele were included.

In the third area, the mountain foreland, all 8- and 13-yearolds in the communes of Dorotea and Vilhelmina were included.

For practical reasons, the study did not include any 4-yearolds outside the city of Umeå.

56 eight-year-olds and 43 thirteen-year-olds were selected for the methodological study of the recall technique (II). These children included nearly all of those in the original material residing in two areas in the city of Umea with large school cafeterias. 
For the haematological study a fourth age group was added, consisting of 80 one-year-old children from the city of Umeå, who were not included in the general survey (IV).

Socio-economic conditions: The number of children per family was greater in the rural areas than in the city of Umeå. The parents of the urban children had a higher level of education than did the parents in the two rural areas, between which there was no difference in this respect. About 80 per cent of the parents in the rural areas had had only elementary school education, compared with 34-56 perr cent in the city of Umeå. In the city, 17-29 per cent had had more than 12 years of formal education. For all age groups, the parents'median combined total incomes were significantly higher in the city of Umeå than in the rural areas, which did not differ in regard to income. The family dwelling space per person was larger in the city of Umeå than in the rural areas, between which no difference was found (I).

\section{METHODS}

Methods of dietary investigation: The nutritional content of the diets consumed by the different groups was determined with the aid of a 24-hour recall (I, II). The frequency of the children's consumption of different foods and dishes was recorded by means of an interview method, in this study called the 'food habit history' (I). Socioeconomic data were obtained and recorded in connection with the interviews (I). 
Method of testing the recall technique by applying it to a school meal, using the double-portion method: Double portions corresponding to the amounts consumed were weighed and chemically analysed for protein, fat and iron content, with subtraction of left-overs (II).

Medical and anthropometrical methods: These included a physical examination and determinations of microsedimentation rate and serum albumin. Weight, height and measurements of the triceps and subscapular skinfolds were also recorded (III).

Haematological methods: These included determinations of $\mathrm{Hb}, \mathrm{PCV}$ (haematocrit) and serum transferrin and evaluation of blood smears. A study of bone marrow iron content was performed on a selected group (IV).

Odontological methods: The incidences of dental decay, gingivitis, plaque, enamel hypoplasia, extrinsic stains and supragingival calculus were recorded. Certain anamnestic data regarding oral hygiene and exposure to fluoride were obtained (V).

Statistical methods are described in I, II and VI. 


\section{The usefulness of the recall technique}

A methodological study of the recall technique was carried out, based on 8-and 13 -year-olds' consumption of the school lunch. For both age groups, on a group basis, the differences between the nutrient data (protein, fat, iron and energy) obtained by recall and by weighing and chemical analysis were small. In spite of a

number of possible sources of error in both the double-portion method used and the recall, the results obtained with the two methods gave median values for amounts consumed and for nutrient intakes that were in fairly good agreement (II).

The median values for energy and nutrient content of a given double portion obtained by calculation from food composition tables and by chemical analysis were in good agreement (II).

\section{The food consumption survey}

The food consumption survey showed that, acr ırding to 24hour recall, children in all age groups and a reas consumed diets that were similar from the nutritional standpoint. For all age groups, the energy and nutrient contents of the diet were calculated from the 24-hour recall and related to the recommendations of the US Food and Nutrition Board (11), and, with respect to fat, in relation to the mean recommendation $(30$ per cent of the energy intake; variation proposed: $25-35$ per cent) of the Swedish National Institute of Public Health (23). 
The 4-yea $\mathrm{r}$-old group.

The average intakes of energy and the principal nutrients in the diet in per cent of recommendations $(11,23)$ a re shown in Fig. 1. The arrow indicates the recommended level. Supplementary vitamin $D$ was not included in the calculations of the vitamin $D$ content of the diet.

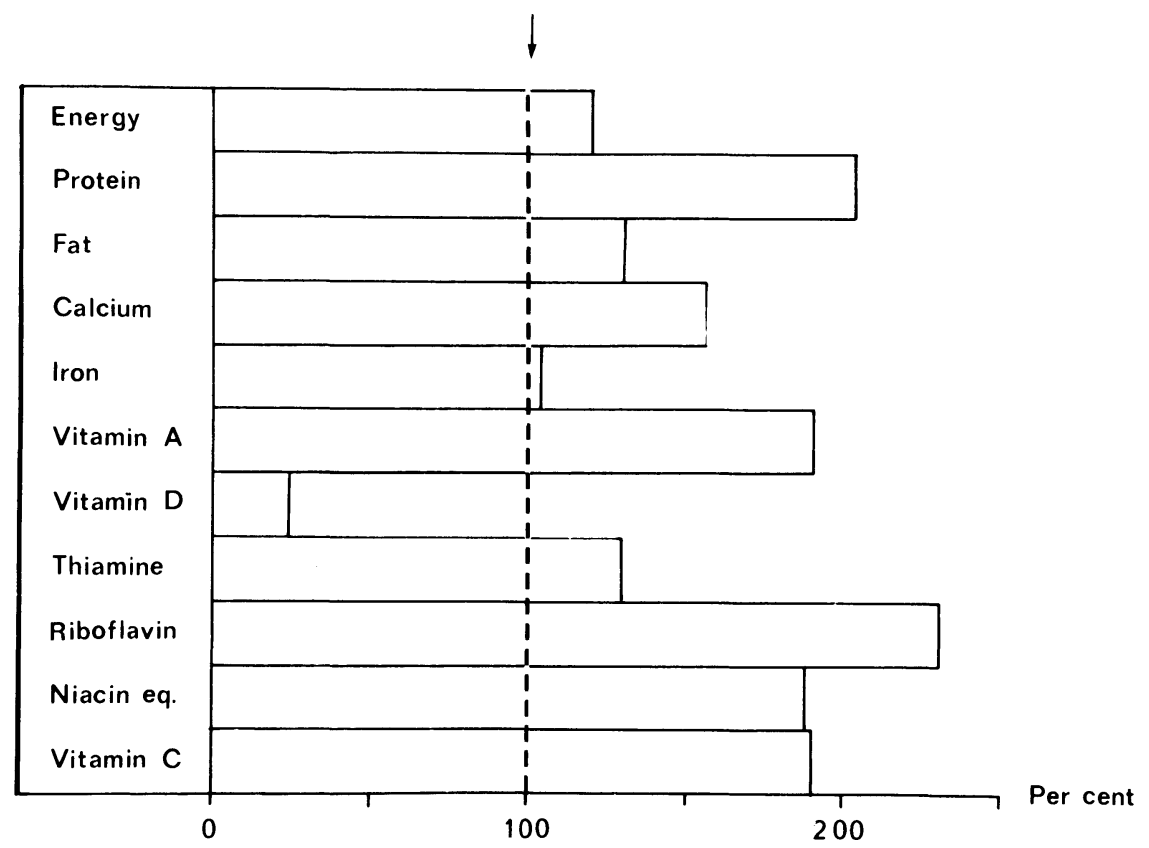

Fig. 1 The 4-year-old group. Mean energy and nutrient intakes in per cent of recommendations. 
As seen in Fig. 2, 18 per cent of the total daily energy intake came from breakfast, and most of the energy was supplied by lunch and dinner. Only 7 per cent of the energy intake came from betweenmeal consumption, mainly of sweets, soft drinks and buns.

14 per cent of the total daily energy intake came from protein. Protein intake was fairly evenly distributed among the day's meals.

40 per cent of the energy intake came from fat. This was also the percentage of the energy intake from breakfast supplied by fat, whereas the corresponding percentages for lunch and dinner were 46 and 47 per cent respectively.

\section{er cent}

100

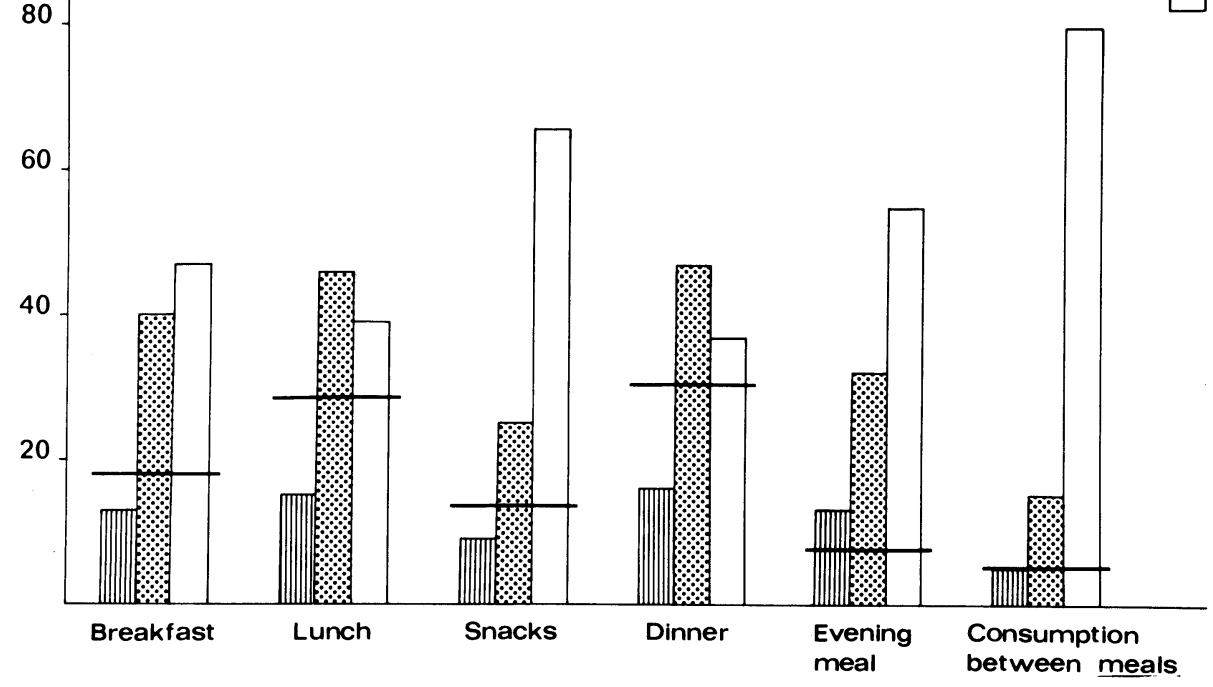

Fig. 2 The 4-year-old group. Percentage distribution of energy among different meals during the day and the percentage distribution of energy among protein, fat and carbohydrate by meal. 
About one-third of the energy and fat in the diet and more than half of the protein came from milk and milk products (Table 2). One-third of the iron intake came from meat, fish and eggs, and almost as much from cereal products and bread, which in Sweden is mostly baked from iron-enriched flour $(5 \mathrm{mg}$ iron/ $100 \mathrm{~g}$ flour; since $1971,6.5 \mathrm{mg}$ iron/100 g flour).

Table 2 The 4-year-old group. Percentage distribution of total amount, energy and some nutrients among different food groups.

Total Ener- Pro-Fat Carbo-Cal-Iron Vit. Vit. Thia-Ribo- Nia- Vit. amount gy tein hydra-cium $A D$ mine flavin cin $C$ te

\begin{tabular}{|c|c|c|c|c|c|c|c|c|c|c|c|c|c|}
\hline $\begin{array}{l}\text { Vege- } \\
\text { tables }\end{array}$ & 3 & 1 & 2 & 0 & 1 & 1 & 4 & 1 & 0 & 2 & 1 & 2 & 11 \\
\hline $\begin{array}{l}\text { Fruit } \\
\text { and } \\
\text { berries }\end{array}$ & 11 & 6 & 2 & 1 & 12 & 2 & 6 & 1 & 0 & 8 & 3 & 6 & 47 \\
\hline $\begin{array}{l}\text { Potatoes } \\
\text { and root } \\
\text { vegetables }\end{array}$ & 7 & 5 & 3 & 0 & 9 & 1 & 8 & 5 & 0 & 12 & 2 & 14 & 13 \\
\hline $\begin{array}{l}\text { Milk and } \\
\text { milk pro- } \\
\text { ducts }\end{array}$ & 52 & 32 & 51 & 38 & 22 & 88 & 14 & 26 & 12 & 31 & 72 & 13 & 21 \\
\hline $\begin{array}{l}\text { Meat, fish } \\
\text { and eggs }\end{array}$ & 9 & 17 & 28 & 30 & 2 & 3 & 32 & 41 & 19 & 26 & 16 & 43 & 2 \\
\hline $\begin{array}{l}\text { Cereal } \\
\text { and } \\
\text { cereal } \\
\text { products }\end{array}$ & 7 & 17 & 13 & 5 & 32 & 3 & 31 & 3 & 12 & 20 & 4 & 17 & ( \\
\hline $\begin{array}{l}\text { Butter, oils, } \\
\text { margarine }\end{array}$ & 2 & 11 & 0 & 26 & 0 & 0 & 0 & 23 & 56 & 0 & 0 & 0 & 0 \\
\hline $\begin{array}{l}\text { Sugar and } \\
\text { candy }\end{array}$ & 9 & 11 & 1 & 1 & 22 & $z$ & 5 & 0 & 0 & 1 & 2 & 3 & 6 \\
\hline
\end{tabular}


Composition of breakfast. According to recall, the most common breakfast consisted of milk or chocolate milk plus sandwiches or buns. 5 per cent of the children ate no breakfast whatever.

General food habits. The overall pattern of consumption of different foods and dishes, as obtained in the 'food habit history', is shown in Figure 3.

Per cent

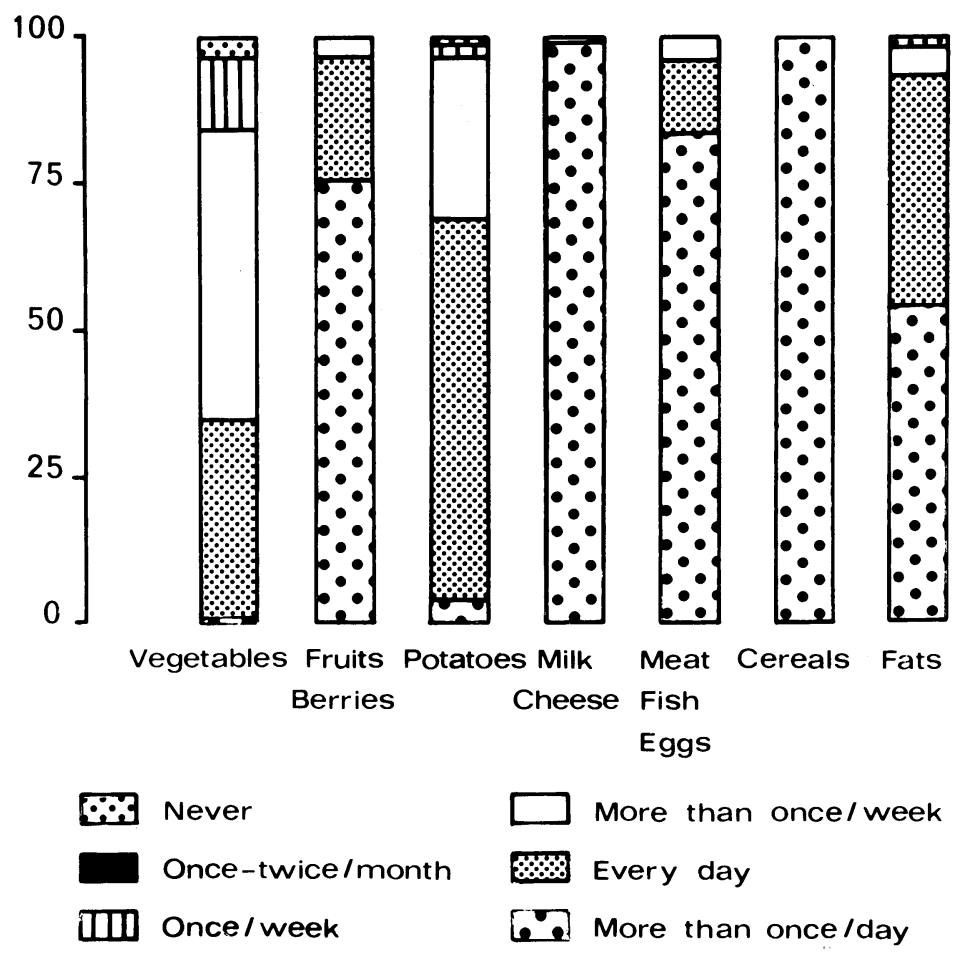

Fig. 3 The 4-year-old group.

The figure shows that 35 per cent of the children ate vegetables daily, 96 per cent consumed berries or fruit daily, 70 per cent ate potatoes and 96 per cent ate meat, fish or eggs daily. All the children consumed bread and butter or margarine and drank milk daily. 60 per cent consumed sweets or other products 


\section{The 8-year-old group}

The nutrient content of the diet was about the same in the three areas, and, in relation to recommendations, the pattern was largely the same as for the 4-year-olds (Fig. 1). In all areas, the average fat content of the diet was 42 per cent of the energy intake. The amount of vitamin D supplied by the diet in the three areas was 23-59 per cent of the recommended amount. The distribution of energy and nutrient intake among the day's meals and among different food groups was largely the same as for the 4-year-old group (I).

The distribution of energy intake among the day's meals was the same for the children in the different areas (I).

The energy supplied by protein was rather evenly distributed among the day's meals and was the same in the three areas. 13 per cent of the total daily energy intake came from protein (I).

The distribution of energy and nutrients among different food groups in all areas was about the same as for the 4-year-old group (Table 2 ).

Composition of breakfast. In the three areas, 5-9 per cent ate no breakfast. The most common breakfast consisted of hot chocolate or tea, sandwiches and/or buns (I).

School lunches. In all areas, the nutrient content per $1000 \mathrm{kcal}$ of the school lunches consumed generally complied with the recommendations (22) except that there was a high fat content and a somewhat low content of iron (I). 
General food habits. Only 16 per cent of the children ate vegetables daily. Fruit or berries were consumed daily by 96 per cent, and potatoes by 74 per cent. Nearly all daily consumed milk and milk products, bread, butter or margarine and some item from the group meat, fish and eggs. Sweets or other products containing sugar were consumed more than once daily by about 60 per cent.

There were differences between the areas with respect to the frequency of consumption of individual foods and dishes. The urban children more often ate vegetables, fruit, fish, blood pudding and liver. Children in the rural areas, on the other hand, had a more frequent consumption of berries, potatoes, porridge, gruel and traditional cereal dishes (I).

The 13 -year-old group

The average contents of fat, iron and vitamin D did not comply with recommendations. In all three areas, the fat content in the children's diets exceeded the recommended intake. For girls, the average iron intake was 64-81 per cent of that recommended, lowest in Umeå, highest in the mountain foreland. For children in all three areas, the average dietary supply of vitamin $\mathrm{D}$ was below that recommended. Other nutrients met or exceeded the recommendations (I).

The distribution of energy among the day's meals and among protein, fat and carbohydrate was generally the same in all areas and was similar to that for the other age groups studied (I). This was also true of the percentage distribution of energy and nutrients among different food groups (I). 
The supply of protein was fairly evenly distributed among the meals of the day. In all areas, 13 per cent of the total energy content of the diet came from protein. There were no differences between the areas.

In all areas, the average fat content of the diet was 42 per cent of the energy intake.

Composition of breakfast. According to recall, 4-5 per cent of the children in all areas ate no breakfast. No hot prepared breakfast were consumed in Umeå, but in the inland area and the mountain foreland, 8 and 12 per cent respectively consumed such a breakfast. The most common breakfast consisted of tea or milk and sandwiches and/or buns (I).

School lunches. The school meals were of the same type in all areas (I). The nutrient content per $1000 \mathrm{kcal}$ generally met the recommendation, except for a high fat and somewhat low iron content (22).

General food habits. The overall pattern of consumption, according to the 'food habit history', was the same in all areas, if consumption is classified according to food groups. The pattern of consumption frequency was about the same as for the 8-year-olds.

There were significant differences between the areas in the frequency of consumption of individual foods and dishes of about the same type as in the 8 -year-old group (I). Children in the city of Umeå more often consumed fruit between meals, whereas the rural children's between-meal consumption more often was of sweet baked goods, soft drinks and juice (I). 
Relation of nutrient content to energy intake for the 4-, 8-and 13yea r-old groups.

The mean contents of protein, calcium, iron, thiamine, and niacin in the diets of children of different ages and sexes were clearly correlated to the energy content. The protein and calcium contents varied between 32-35 g and 600-700 mg per $1000 \mathrm{kcal}$ respectively. The iron in the diet varied between $5.8-6.3 \mathrm{mg}$ per $1000 \mathrm{kcal}$.

\section{The medical and anthropometrical investigation}

The children's general health and nutritional status was good, and this was also reflected in the serum albumin levels (III). No nutritional deficiency states were discovered.

In all age groups there was a fairly high frequency of subclinical upper respiratory infections, reflected in elevated ESR's. 38 per cent of the 4-year-olds had an ESR over $20 \mathrm{~mm}$. For the 8 - and 13 -year-olds, the corresponding figures in the three areas varied between 12-21 per cent and 18-21 per cent respectively (III). The girls in all age groups had higher mean and median skinfold thicknesses than the boys. The skinfold measurements of the urban children were significantly greater than those of the children in the mountain foreland, except for the triceps skinfold measurement of 13-year-olds. In the city of Umeå, 8-and 13-year-olds were also somewhat taller ( $p<0.01$ and $p<0.05$ respectively), on an average, than the children in the mountain foreland.

\section{The haematological investigation}

In the 1 -year-old group, one boy and in the 13-year-old group, two girls proved to have iron-deficiency anaemia (IV). The 
prevalence of iron-deficiency anaemia in the 4-, 8- and 13-yearold children taken together was 0.1 per cent. Among the 13 -yearold girls it was 0.6 per cent. No other ha ematological diseases were diagnosed. The children in the city of Umea had lower mean $\mathrm{Hb}$ and/or PCV values than the children in the mountain foreland. The average intake of iron increased from coast to inland to mountain foreland in all age groups studied. However, there was no close parallel between average iron intake and the $\mathrm{Hb}$ values in the different areas.

A special, more detailed haematological investigation, including bone marrow studies, was conducted on the children who had low $\mathrm{Hb}$ and/or PCV vahues (the mean - 2 S. D.) in the field study. This investigation included 30 children, and of these, only the three mentioned above proved to have iron-deficiency anaemia. The other 27 all had stainable iron in their bone marrows. In this group of children there was a higher incidence of recent or subclinical infections: 48 per cent of the 27 had an ESR above $20 \mathrm{~mm}$, compared with 20 per cent in the total material.

\section{Oral health studies}

The odontological examination showed that in the 4-year-old group 14 per cent had more than 10 decayed teeth. Only 17 per cent were entirely free of caries, and only 3 per cent had healthy gingivae. In the 8 -year-old group, the corresponding figures were 0.4 per cent and 0.7 per cent respectively, and in the 13 -year-old group, 0 per cent and 2 per cent respectively. 
Only in the 13-year-old group were significant sex differences noted in the caries indices (DMFT). This index was higher $(\mathrm{p}<0.001)$ in girls than in boys, as was also the number of erupted permanent teeth $(\mathrm{p}<0.001)$. In the 13 -year-old group, boys, on the other hand, had significantly higher gingival index than girls $(p<0.01)$. The plaque index was significantly higher for boys in both the $8-(p<0.05)$ and 13 -year-old groups $(p<0.001)$. The frequency of tooth brushing was lower for boys than for girls (V).

There were significant differences between the three areas in the caries indices and the plaque and gingival indices, with the lowest values in the city of Umeå. There were also clear differences between the areas with respect to the frequency of tooth brushing, with the highest frequency in the city of Umeå (V).

\section{$\underline{\text { Relationship between general and oral health, food habits and }}$} socio-economic conditions

Multiple regression analyses showed that there were correlations between general and oral health, food consumption frequency and socio-economic conditions. It should be observed that, as the material was relatively large, a slight influence of one variable on another may cause statistical differences. The results of the analyses are given in diagrams (VI). The diagram for the 4-yearolds (Fig. 4) shows that the total frequency of consumption of sweets was positively correlated to the caries index (deft) and plaque indices. Socio-economic conditions influenced the frequency of consumption of different foods, e.g. a higher educational level of the parents decreased the children's consumption of sweets, and increased the consumption of vegetables. 


\section{VARIABLES}

Total frequency of

consumption

VARIABLES

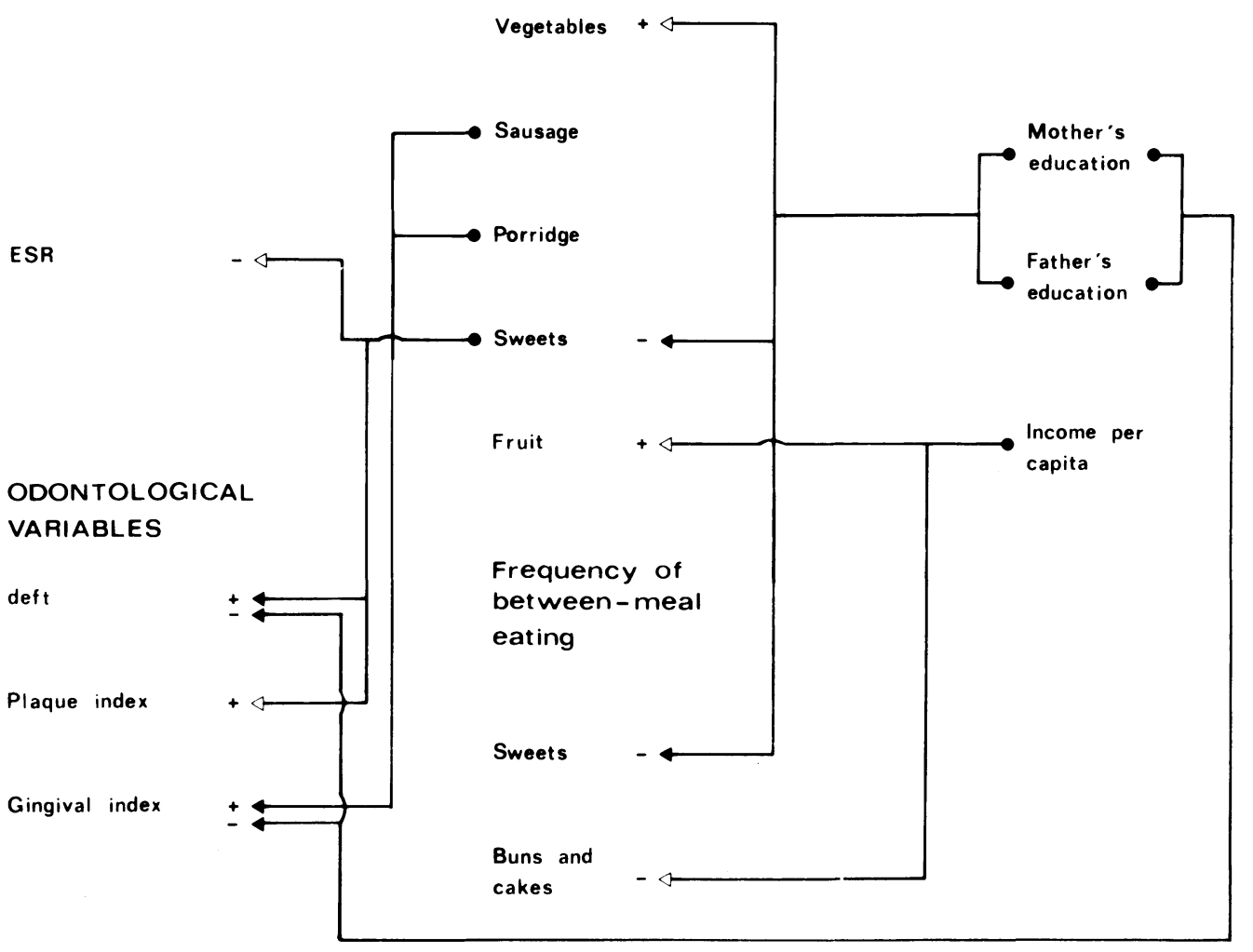

Fig. 4 Results of the multiple regression analysis. The 4-yearold group. City of Umeå. The relationship between medical, odontological, food frequency consumpt on and socio-economic variables. The light and shaded arrows denote significant effects at the 1 per cent and 0.1 per cent levels respectively. A minus sign preceding an arrow denotes a negative effect and a plus sign a positive effect on the regressand by an increase of the regressor. 
Children of parents with a higher level of education had, on an average, lower deft values and lower gingival indices.

For 8-and 13-year-olds in the city of Umeå, as well as in the two rural areas taken together, both medical and odontological variables were affected by socio-economic conditions and diet. Frequent consumption of porridge, for example, and of buns and cakes between meals, negatively influenced the $\mathrm{Hb}$ and PCV values and the body weight respectively. Frequent consumption of sweets and of buns and cakes increased the caries indices (Gerdin's index, DMFT) and body weight.

For both 8-and 13 -year-olds, a greater number of erupted permanent teeth and higher body weight and/or height increased the DMFT values. For the 8-year-olds, frequent tooth brushing decreased the plaque index, and for the 13-year-olds, frequent tooth brushing gave both a lower plaque index and a lower gingival index. The caries indices were not correlated to the frequency of tooth brushing.

Concerning socio-economic conditions, higher educational levels of the parents decreased the caries indices, except for the 8 -year-olds in the rural areas. 


\section{GENERAL DISCUSSION}

Since the child material in the present study was large, was selected at random in the city of Umeå, and, in the rural areas, included the total child population in the age groups studied, the results can be regarded as representative for the children in this part of Sweden.

In the food consumption survey the nutrient content of the children's diet and their food habits were determined by a 24 hour recall and a food habit history respectively. The methodological study of the recall technique showed that 8 - and 13 -year-olds were able to give an acceptable picture of their consumption of a school meal on a group basis (II). It can be assumed that individual errors in the estimation of food consumption will be levelled out on a group basis. Other meals during the day would have been impossible to study without the risk of interfering with the usual daily food habits. There does not seem to be any reas on to believe that such information would be less accurate for the other meals during the 24-hour period studied. A supplementary interview with the mother is necessary in all dietary interviews with children below 12-14 years of age, especially for information about food preparation. These findings are supported by the findings of Beal (2). If the recall for the past 24 hours is supplied by both the mother and the child and the material is large, as in the food consumption survey (I), the method will be sufficiently accurate for determining the nutrient value of the diet consumed on a group basis. Otherwise the 
weighing method is the only one which gives accurate quantitative information. This has recently been pointed out by Flores (10) in a review of dietary surveys from both non-industrialized and highly-developed industrial countries.

The food habit history, on the other hand, was suitable for determining the frequency of consumption of different foods, which was intended to reflect the childrens' food habits on an individual basis.

The total energy intake of the 4-year-olds was about the same as that reported in British studies by Bransby (4) and Widdows on (26), but higher than the intake reported in the Health Departments Survey (19) and in earlier studies from the USA (1). In comparison with later studies from the USA, the difference in energy intake is small (7). For the 8-and 13 -year-olds, the energy intake was about the same as in other comparable studies $(6,24,26)$. However, with respect to energy intake per $\mathrm{kg}$ body weight, there were differences, probably reflecting variations in growth and physical activity, In spite of having a higher average energy intake, the children in the mountain foreland had lesser skinfold thicknesses than the children in the city of Umeå (III). These regional differences presumably reflect the effect of greater physical activity on the part of the rural children.

Both means and S. D. for height and weight were similar to recent comparable anthropometrical data on children in the city of Stockholm (14). The skinfold thicknesses, however, were higher in the Stockholm children than in the children in Västerbotten, 
even higher if compared with the measurements for the rural children alone, especially the children in the mountain foreland (III). This may support the above statement concerning the effect of physical activity.

The high fat content of the diet was about the same as that observed in many other food consumption studies of children in Western Europe and the USA $(1,5,8,12,13,15,21,24,25)$. It is interesting to note that in the present study about one-third of the fat content was derived from whole milk and milk products, and one-third from butter and margarine (I). It is evident from this study that milk plays a central role in the diet of Swedish children, which also results in a high protein intake. A corresponding high intake of protein has been reported in other nutritional studies of infants and children $(5,7,8)$. The protein content of the diet is probably unnecessarily high (I).

Iron intake from the diet was satisfactory in relation to recommendations, except for the 13-year-old group. In this age group two cases of iron-deficiency anaemia were found, both in girls. The direct cause, however, was not dietary, but excessive loss of iron in menstruation (IV). These cases illustrate that girls with profuse menstrual bleeding run a risk of developing iron-deficiency anaemia if the diet does not contain sufficient iron (IV). The diet that the investigated children consumed had about the same iron content as the average diet in Sweden (27). A high consumption of bread baked from iron-enriched flour may be one of the reasons for the favourable iron intake of the children in the present study, which was reflected in a low incidence of iron-deficiency anaemia in all age groups (IV). 
On the other hand there is reas on to believe that recent or subclinical upper respiratory infections caused depressed haemoglobin values (IV).

Concerning the low vitamin $\mathrm{D}$ content of the diet in relation to the recommendation of the Food and Nutrition Board (11), other investigations of the vitamin D content of the Swedish diet have shown the same results (12). It is, however, impossible to know whether the recommendation actually was met through the addition of the effect of sunlight and/or the fact that 65 per cent of the 4-year-olds and 15-16 per cent of the 8-, and 13-year-olds also received vitamin $\mathrm{D}$ supplements. The supply was probably satisfactory because no rickets or post rachitic states were found. It is hardly possible to meet the current and proposed recommended intake by diet alone, since there are few good dietary sources of vitamin D. An expert group appointed by $\mathrm{FAO} / \mathrm{WHO}(9)$, has proposed that the recommended dietary intake of vitamin $D$ be reduced to $2.5 \mu \mathrm{g}$ for children 7 years of age or older, but that $10 \mu \mathrm{g}$ be retained as the recommended intake for younger children.

There was a tendency for more complete breakfast to be eaten in the rural areas in comparis on with the city of Umeå, perhaps because of the persistence of more traditional food habits in the rural areas.

The school meals, which were of the same type in all areas, generally met the Swedish recommended dietary allowances (22) for all nutrients, except for fat and iron content. The fat content was as high as in other meals during the day, and the iron content was about the same as in the present average Swedish diet $(12,27)$. 
Carbohydrate-rich between-meal consumption, mainly of sweets and buns and cakes was very common. This consumption was insignificant from the standpoint of nutrient intake. However, higher frequencies of consumption of sweets, buns and cakes between meals were correlated to higher caries indices (VI). Therefore it must be of utmost importance to decrease such between-meal consumption.

The somewhat one-sided consumption of milk and cereal products that was found, especially in the two rural areas, is partly similar to the diet described by Odin in his investigation of the same area in 1929-31 (20). He stated that there were three different types of diets in the county, with different types of transitions from one area to another. In the coastal area, the adult population consumed a lacto-cereal diet. Cereal products, milk, barley gruel and porridge, potatoes, crispbread and herring formed the common diet. Herring was the basis of the standard breakfast. Farther inland the predominant diet consisted of pork, meat, 'palt' and bread. In the mountain areas, the diet also included fish, due to the abundance of fish in the mountain lakes. In the towns there was a third type of diet, which was more varied, but which had a lacto-cereal base. Among school children, the lacto-cereal diet predominated in all areas and usually included local cereal dishes such as 'palt', thinbread in milk or in hot broth, and wheat meal and water cooked in milk. The adult diet in the different a reas naturally also influenced what was served to the children. In all parts of the county, the diet at that time rarely contained fruit or vegetables. A diet richer in vitamin C 
was consumed by only 20.5 per cent of the children.

The type of diet that children consumed today, 40 years after Odin's investigation, shows clear changes in composition, but a diet rich in milk and cereal products is still present, mainly in the rural areas. The consumption of fruit has increased, but the frequency of fruit consumption is higher in the city of Umeå and in the mountain foreland, with its larger villages, than in the inland area, which is almost completely rural. Berries and potatoes are consumed more often in the inland area and in the mountain foreland compared with the city of Umeå, probably due to the fact that there is easier access to these foods in these areas. Common to all areas is the fact that vegetables are fairly rare in the diet. This appears from both the food habit history and the 24 -hour recall.

The regional differences which were found in socio-economic conditions, in the food frequency consumption pattern and in oral hygiene certainly contribute to the explanation of the differences in caries, plaque and gingival indices between the areas, with the lowest values among the urban children.

In this study, multiple regression analysis (VI) showed that better socio-economic conditions, often including a higher educational level, had a direct effect on the frequency of consumption of different foods. It is of interest that for the 13 -year-olds in the city of Umeå, better socio-economic conditions were positively correlated to the consumption of vegetables, berries and fish and negatively correlated to the consumption of, for example, sweets, buns and cakes. 
These findings are very similar to those of Biörck et al. (3) in their study of families in two towns in the southern and western parts of Sweden in the 1950's. In that study, the findings were related to the families's ocial class instead of the educational level.

Better socio-economic conditions were negatively correlated to the frequency of consumption of sweets and buns and cakes, consumption which negatively affected the caries indices. This is in accordance with Koch and Martinss on (16), who showed that the caries status of groups of 14 -year-olds was correlated to several social factors, especially the parent's educational level and the family's social class. In the present study (VI) it has been shown that both food and socio-economic factors exerted an influence on medical and odontological health status, and that neither type of factor predominated (VI).

The effects of frequent consumption of other foods on medical and odontological status are more difficult to explain. It is possible that frequent one-sided consumption of lacto-cereal dishes will result in statistically somewhat lower $\mathrm{Hb}$ and PCV values as found in the 13 -year-old group.

This investigation clearly shows that food habits a re established at an early age. The fact that both the pattern of food consumption and the nutrient content of the diets were so similar in all age groups and in all areas suggests that this is the case. This study also shows that food habits have changed during the past 40 years. Positive changes include the present more frequent consumption of fruits and vegetables, and the consumption of bread baked from iron-enriched flour. A negative change is the trend toward the inclusion of more fat and sugar products in the children's diet today. 
Food habits were found to be influenced by the family's socioeconomic conditions, and both food habits and socio-economic conditions had a decisive influence on general and oral health.

\section{SUMMARY}

Groups of 8-, and 13-year-old children were able to provide an acceptable picture of their consumption of a single meal in a dietary recall covering the past 24 hours. There was relatively good agreement on a group basis between what the children reported in the recall and their actual consumption as checked by the doubleportion technique.

In all age groups studied the children consumed a diet which, in relation to recommendations, was rich in fat and protein, and which had a relatively low iron content for the 13-year-olds, and a low vitamin $\mathrm{D}$ content for all age groups. Frequent carbohydraterich between-meal consumption was common, especially in the rural areas. Breakfasts were often incomplete from the standpoint of nutrient intake, whereas the school meals met the recommendations for Swedish children, with the exception of fat and iron content.

The frequency of consumption of different foods and dishes showed regional differences, with more traditional food habits in the rural areas, in contrast to somewhat more varied food habits among the urban children.

The general health of the children was good. Subclinical upper respiratory infections were common. Differences in anthropometrical data were found between the sexes and between the areas, with higher skinfold thicknesses in girls and, in part, in urban children. The regional differences may be due to differences in physical activity. 
The prevalence of iron-deficiency anaemia among 4-,8- and 13 -year-olds children taken together was 0.1 per cent. Among the 13 -year-old girls it was 0.6 per cent. Among the children with $\mathrm{Hb}$ and/or $\mathrm{PCV}$ values $\leq$ the mean $-2 \mathrm{~S} . \mathrm{D}$., there was a higher incidence of subclinical infections than in the material as a whole.

There was a high frequency of caries in all age groups. Only 17 per cent of the 4 -year-olds, and 0.4 and 0 per cent of the 8 - and 13 -year-olds respectively were caries-free. Caries, plaque- and gingival indices were higher in the rural areas. The frequency of tooth brushing was lower in the rural areas than in the city of Umeå.

In the analysis of the relationship between general and oral health, food habits and socio-economic conditions it was found that both socio-economic conditions and the frequency of consumption of different foods influenced general and oral health. 


\section{ACKNOW LEDGEMENTS}

I wish to express my gratitude to Professor Stig Sjölin, now Professor at the Department of Paediatrics, University of Uppsala, for his valuable support and advice during all stages of the investigation.

My thanks are also ciue to Professor Arvid Wretlind, Karolinska institutet, Stockholm, for valuable discussions and for his permitting me to perform special parts of the study at the Swedish National Institute of Public Health.

I am very much indebted to Professor Hans Grahnén, my collaborator in the odontological section, for valuable and constructive criticism.

Assistent Professor Gunnar Eklund, Uppsala and Erik Arvidsson, Fil. kand., Umeå, gave me invaluable assistance with the statistical problems.

For skilful technical assistance during the field studies I wish to thank Mrs Greta Mörén and Miss Eva Appelberg.

My thanks are also due to Barbara Steele, Fil. lic., for the translation, Mrs Mayvor Burwall for her skilful typing of the manuscript and Miss Yvonne.Erikss on for valuable help with the figure drawings.

The investigation was supported by grants from the Bank of Sweden Tercentenary Fund, from the State Grant for the Promotion of Medical Research and from the Swedish Patent Revenue Research Fund. 


\section{REFERENCES}

1. Beal, V.A.: Nutritional intake of children. I. Calories, ca rbohydrate, fat and protein. J Nutr, 50: 223, 1953.

2. Beal, V.A.: The nutritional history in longitudinal research. Amer J Dietet Ass, 51: 426, 1967.

3. Biörck, G., Persson, R. \& Nystrand, B.: Något om kostvanor och deras bakgrund $i$ en svensk befolkning. Soc Med Tidskr 32: $375,1955$.

4. Bransby, E. R. \& Fothergill, J.E.: The diets of young children. Brit J Nutr, 8: 195, 1954.

5. Bresard, M. \& Chabert, C.: Enqûete sur l’álimentation et le genre de vie de groupes d'écoliers de 1 'enseignement primaire a Marseille, Bull Inst Nat Sante, 24: 291, 1969.

6. Burke, B.S., Reed, R. B., van den Berg, A.S. \& Stuart, H.C. : Caloric and protein intakes of children between 1 and 18 years of age. Pediatrics, 24: 922, 1959.

7. Crumrine, J. L. \& Fryer, B.A.: Protein components of blood and dietary intake of preschool children. J Amer Dietet Ass 57: 509,1970 .

8. Debry, G., Manciaux, M. \& Comoy, J.: L'alimentation spontanée de ${ }^{\prime}$ 'enfant agé de un et demi a trois ans et demi (Étude sur 44 enfants par la méthode des enquêtes alimentaires individuelles par pesées). Bull Inst Nat Sante, 21: 219, 1966.

9. FAO/WHO Expert Committee on Nutrition. Requirements of ascorbic acid, vitamin $\mathrm{D}$, vitamin $\mathrm{B}_{12}$, folate and iron. FAO Nutrition Meetings Report Series, No. 47; Wld Hlth Org techn Rep Ser, No. 452, Geneva, 1970.

10. Flores, M.: Preschool child food consumption surveys, lecture held FAO/WHO/UNICEF, Protein Advisory Group Meeting, Geneva, 1970. 
11. Food and Nutrition Board: Recommended dieta ry allowances.

Seventh revised edition, 1968. National Research Council, Publication No. 1694, Washington D. C., 1968.

12. Hellström, V. \& Wretlind, A.: Die Ernährungs-situation in Schweden. Ernährungs-Umschau, 4: 141, 1970.

13. Karlberg, P., Bergsten, K., Carlgren, G., Isaksson, B., Karlberg, G., Lundgren, S. \& Odenman, I.: Kosten hemma för barn under 3 år. Äta rätt i barnaåldern. Findus symposium, Stockholm, 1968.

14. Ka rlberg, P., Engström, I. , Lichtenstein, H. , Klackenberg, G. , Klackenberg-Larsson, I., Stenss on, J., Svennberg, I. \& Taranger, J.: Personal communication, 1971.

15. Kelsay, J. L.: A compendium of nutritional status studies and dietary evaluation conducted in the United States 1957-1967. J Nutr, 99: Suppl. 1:119, 1969.

16. Koch, G. \& Martinsson, T.: Socio-odontological investigation of school children with high and low caries frequency. I. Socioeconomic background. Odont Rev, 21: 207, 1970.

17. Mellander, O., Vahlquist, B. \& Mellbin, T.: Breast feeding and artificial feeding. A clinical, serological and biochemical study in 402 infants with a survey of the literature. The Norrbotten Study. Acta Paediat Scand, 48: Suppl. 116, 1959.

18. Mellbin, T.: The children of Swedish nomad lapps. A study of their health, growth and development. Acta Paediat Scand, 5l: Suppl. 131,1962 .

19. Ministry of Health: A pilot survey of the nutrition of young children in 1963. Reports on Public Health and Medical Subiects No. 118 H.M. Stationary Office, London, 1968. 
20. Odin, M.: Sjukdomar och sjukdomsfrekvens i övre Norrland särskilt med hänsyn till födans sammansättning. En Socialhygienisk undersökning i Västerbottens och Norrbottens län, 1929-1931. Håkan Ohlss ons boktryckeri, Lund, 1934.

21. Ryd, G. \& Wretlind, A.: Personal communication, 1971.

22. Skolöverstyrelsen (Swedish Board of Education): Ny närings rekommendation för skolmåltider (Recommended dietary allowances for school lunches in Sweden), Stockholm, 1970.

23. Statens institut för Folkhälan. (Swedish National Institute of Public Health). Önskvärd halt av näringsämnen per 1000 kcal. Vår Föda, 21: 167, 1969.

24. Sterky, G.: Consumption of calories and nutrients by diabetic and non-diabetic school children. A dietary study based on the 24-hour recall method. Acta Paediat Scand, 51: Suppl. $135: 185,1962$.

25. Söderberg, S.: Konsumtion av näring sämnen bland kontors a rbetande och studerande flickor. Soc Med Tidskr, 35: 3, 1958.

26. Widdows on, E. M. : A study of individual children's diets. Medical Research Council, London, H. M. Stationary Office, Spec Rep Ser No. 257, 1947.

27. Wretlind, A.: The supply of food iron. In Blix, G. (Ed.) Symp Swed Nutr Found VI. Occurrence, causes and prevention of nutritional anaemias. Almqvist and Wiksell, Uppsala, p. $73,1968$. 